\title{
Hyperpoliticised internationalisation in a pariah university: an Israeli institution in the occupied West Bank
}

\author{
Bamberger, A. Morris, P. Weinreb, Y. Yemini, M.
}

Keywords: internationalisation; higher education; rationales; strategies; enactment; conflict; Israel; the West bank.

\begin{abstract}
Internationalisation in higher education tends to be portrayed as a value-neutral intervention driven predominately by economic motives yet advocated and prescribed for humanitarian purposes. In this study we investigate how internationalisation takes shape in an institution which is characterised by political controversy that hinders and shapes its internationalisation efforts; we explore the rationales for and enactment of internationalisation at Ariel University (AU), Israel's only university located in the West Bank, part of the occupied Palestinian territories (oPt). We challenge the dominant framing of internationalisation in higher education and shed light on the nature, purposes and forms of internationalisation.
\end{abstract}

\section{Introduction}

Internationalisation is increasingly portrayed as a key feature of higher education (HE) systems around the world and has been described as a universal phenomenon (Chankseliani, 2018; Larsen, 2016; Warwick \& Moogan, 2013). While it is recognised that internationalisation has multiple overlapping political, economic, academic, and sociocultural rationales (de Wit, Hunter, Howard, \& Egron-Polak, 2015), historically these are usually depicted as moving from the pursuit in the post-World War II period of peace and mutual understanding; to aid and development in the Cold War period, to the contemporary period dominated by economic motives (e.g. de Wit, 2002; Knight, 2015 Qiang, 2003). While other more humanistic aims for internationalisation (e.g. multiculturalism, cosmopolitanism, global citizenship) are widely advocated, in practice, economic motives tend to be viewed as the defacto driving force (Brandenburg and de Wit, 2011). The economic framing of internationalisation focusses particularly on the mobility of staff and students across national borders and assigns them a strong degree of agency/autonomy. Despite criticism regarding the connections between internationalisation and neoliberalism, colonialism and Western 
values, internationalisation is associated with optimistic and humanistic connotations and tends to be presented as an ideologically neutral, worthwhile and normalised intervention (Authors, forthcoming; Morley et al, 2017; Stein \& Andreotti, 2017).

We investigate how internationalisation takes shape in an institution which is characterised by political controversy that hinders and shapes its internationalisation efforts. Ariel University (AU) is an Israeli institution located in the West Bank, a part of the occupied Palestinian territories (oPt) ${ }^{1}$ which are internationally recognised as both Palestinian and occupied by Israel. It is thus subject to boycotts and bans by many funding organisations, institutions and academics both within Israel (Davidovitch \& Iram, 2014) and abroad (Gordon \& Pardo, 2014). The initial supposition is that given the purpose of its founding and the extreme controversy and political turmoil surrounding the institution, internationalisation may be pursued for reasons outside the dominant economic or normative framings and, given its pariah status, internationalisation may also be enacted in distinct ways. While the nature and form of internationalisation within specific HE institutions has been extensively researched (e.g. Schartner \& Cho, 2017; Stromquist, 2007; Svetlik \& Braček Lalić, 2016), it has been critiqued for being of ostensibly limited general applicability (Gao, 2017). Yet, as Berry \& Taylor (2014) note, studies of national and global level patterns of internationalisation tend to reinforce the dominant discourses and present a particularly North American and Eurocentric framing, obscuring nuances and wider perspectives. In contrast we focus on the rationales and strategies of internationalisation in Israel's only university located in the oPt, an institution under extreme controversy and political turmoil, to challenge this dominant framing and to develop broader understanding of the forms, uses and nature of internationalisation. Despite several studies on its establishment, development and operation (e.g. Davidovitch \& Iram, 2014; Davidovitch \& Soen, 2009; Davidovitch \& Soen, 2010; SinuanySten, Davidovitch, \& Drukman, 2016), little research has analysed internationalisation at AU. Further, with few notable exceptions, (e.g. Authors 2014; 2015; 2017; Ben Tsur, 2009) research has not focussed on the role of national conflict on internationalisation in higher

\footnotetext{
${ }^{1}$ There is a variety of value-laden terms applied to this region, which reflect political views. Notably, Judea and Samaria, the official term for the region by Israeli law, denotes a historical and Jewish connection to these lands. We use the term, oPt, which reflects the terminology used by the international community (e.g. the United Nations). At times in this paper interview participants, institutions, government and military titles, and official policies will use the term 'Judea and Samaria.'
} 
education institutions (HEIs). As international and comparative education scholars, based in Israel and abroad, we were drawn to explore this case for its many features which we believe provide an impetus to expand our understanding of internationalisation not just in Israel and other nations in conflict, but also more widely.

We draw on multiple sources of evidence including interviews, domestic media coverage and documentary analysis. Seventeen semi-structured interviews were conducted between December 2017 and May 2018 with senior academic staff and university leadership at AU (11); and major stakeholders in Israeli higher education and senior internationalisation professionals in Israel (6). Participants were asked about their academic and/or administrative backgrounds; in what ways they were involved in internationalisation; and the impact the political situation and specifically the international bans have on internationalisation at $\mathrm{AU}$. AU Participants were asked how and why they came to AU. Interviews were audio-recorded, professionally transcribed and thematically analysed according to Bauer and Gaskell (2000). In addition to the interviews we conducted, publicly available interviews with university leadership were analysed from newspapers (3); and television (2). The bulk of the interviews (20/22) and documents were in Hebrew and translation was undertaken as necessary for illustrative quotes. To protect participant anonymity, quotes are given using generic descriptors from the interviews we conducted; publicly available interviews are attributed. Domestic media coverage entailed an analysis of over 100 articles published in the main Israeli newspapers (e.g. Ha'aretz, Yediot Ahronot) relating to the development of AU. Finally, documentary analysis also included a qualitative content analysis (Hsieh \& Shannon, 2005) of the international section of the university website, promotional materials provided by $A U$, and reports provided to us by the Council of Higher Education (CHE), the National Bureau of Statistics, and AU officials. During the study we did not encounter any resistance to our research; participants were interested in the study and fully cooperated. Along with ethics approval from Tel Aviv University, the study received approval from a senior AU official who was also provided with a report of the findings.

We begin by establishing the rationales and strategies of internationalisation and then situate Israeli internationalisation within that literature before turning to the case of $A U$. We then 
analyse the case of $\mathrm{AU}$ with regard to that literature and conclude with a discussion on the broader implications of the study.

\section{Rationales for and the enactment of internationalisation}

The main rationales for internationalisation identified in the literature are academic, sociocultural, political and economic in nature (de Wit et al, 2015). These correspond to different views on its purposes; the different ways it is enacted; and the different stakeholders involved. The academic rationale is the traditional motive for collaboration which is viewed as intrinsic to academia and linked to enhancing the quality of research and HE provision. It is enacted primarily through academic staff and is particularly linked to the internationalisation of research (Woldegiyorgis et al, 2018). The socio-cultural rationales promote internationalisation to enhance mutual understanding, which relates to the internationalisation of the curriculum and also tends to be enacted by academics (Leask, 2001). Political rationales for internationalisation, enacted by governments, are tied to foreign policy and tend to be viewed as a way to garner soft power (e.g. in England, see Lomer, 2017) and world influence (e.g. in China, see Wang, 2014) particularly through mobility programmes, government sponsored scholarships, fellowships and research programmes. The economic rationale tends to be either commercial in nature or for the development and support of a national 'knowledge economy'; these tend to be linked to international student recruitment and fees; institutional mobilities (e.g. branch campuses) and tend to be driven by university administrators/senior management. These rationales are intertwined, mutually inclusive and at times in tension. For example, Marginson (2006) argues that the academic rationale has been co-opted to the pursuit of the 'global knowledge economy' to support the global competitiveness of nations. Thus, while the internationalisation of research may promote the advancement of science and better quality HE provision, it also serves the economic development and political agendas of nations.

As noted earlier the dominant rationales have been portrayed as shifting over time; however, Guo and Guo (2017) argue that the primary shift was actually from political to economic motives, as the peace and mutual understanding rationale after WWII and the development rationale during the Cold War, were motivated by foreign policy and clear political rationales. This shift, from the political to the economic, is traced in turn to a shift in the late 1990s - 
corresponding to the fall of the Soviet Union and the global rise of neoliberalism - to international students serving as important sources of revenue for many institutions in the West. The literature favours this Western narrative and the economic rationale is now portrayed as the driving force behind internationalisation on all levels: nations in a bid for the wider economic benefits of an influx of overseas students and skilled immigration to drive competition in the 'global knowledge economy' (Lomer, 2017; Trilokekar, 2010); institutions in pursuit of financial revenues, international branding, reputation and global rankings (Knight, 2015); and students in the pursuit of the cosmopolitan capital that is perceived to increase access and opportunity in local and global labour markets (Aktas, Pitts, Richards, \& Silova, 2017; Kratz \& Netz, 2018).

The consequences of this neoliberal economic framing of internationalisation is three-fold. Firstly, it tends to normalise internationalisation for economic purposes, de-politicising it, through its role as a key aspect of the global economic race, based around a market, with 'objective' indicators. Despite its linkages to neo-colonialism, inequalities and Western values, Stein et al. (2016) and Morley et al. (2018) argue that the neoliberal framing of internationalisation continues to be presented as an ideologically neutral, and normalised intervention which is often portrayed as an 'unconditional good' (p. 538). Secondly, the focus on global competition between knowledge economies tends to marginalise the domestic aims of internationalisation, perpetuating the view that universities are 'disembedded' from local and national needs (e.g. Beerkens, 2004); thus, the rationales for internationalisation on a domestic level are underinvestigated. Thirdly, despite recognition that there are multiple rationales for and manifestations of internationalisation that are enacted by different actors, the relationship between these areas and how they may work together or in opposition is also underinvestigated. Instead, the focus has been on student mobility (Proctor, 2015) and its enactment is portrayed as a strategic action by universities with the assumption of few constraints and a great deal of autonomy (e.g. Hudzik, 2015).

\section{Internationalisation in Israeli HE}

Since its inception in 1948, Israel has been embroiled in an intractable geopolitical conflict. It was founded as the nation of the Jewish people, yet there is a substantial indigenous Palestinian minority in the country. It is a nation comprised of deeply divided societies with 
diverse national, ethnic, religious and social groups. Albeit military and political in nature, this conflict affects all spheres of Israeli life, including higher education and notably its international aspects. While rationales such as peace-making and multiculturalism are connected to internationalisation, due to the intractable conflict with its neighbours and the ethnoreligious character of the state, the multi-cultural purposes of internationalisation are minimal and limited to relations between majority/minority populations within the state (Authors et al, 2015); the heterogenous Jewish population of Israel (e.g. integrating Jewish immigrants from different backgrounds); and the Jewish diaspora (Authors et al, forthcoming). Despite the growth of international programmes taught in English which charge high fees, enrolment in such programmes remain a small part of the Israeli HE system and thus the financial rationale for internationalisation in Israel is weak. The economic rationale has been growing in recent years as the Israeli economy is increasingly dependent on export markets for its high technology sector, and this rationale is strongly linked with the internationalisation of research. The political aspect of internationalisation has also been growing in recent years and is linked to soft power rationales, particularly as the state has come under increasing scrutiny since the Second Intifada (Palestinian uprising) in 2000; and to efforts to secure and maintain relations with influential nations to ensure political support and economic access to large consumer export markets for the maintenance of its high technology export economy. Thus, the rationale for academic excellence, particularly in research, has been dominant.

Mobility, a principal focus of internationalisation, is limited due to the unpredictable security situation; regulations which restrict movement and possibilities for cooperation both among groups in Israel and across the region; Hebrew as the primary language of instruction; and the founding values of the state as the Jewish nation which limits who may live, work and immigrate to the country (Authors, 2017). However, while mobility is restricted, for Israeli researchers, particularly in elite universities, mobility is also encouraged (to other top-tier institutions or with renowned researchers; regional cooperation is almost non-existent) through generous national funding for sabbaticals and attendance at international research conferences. The combination of a narrow discourse around the purposes of internationalisation and limited mobility, encourages the framing of internationalisation as the pursuit of academic excellence (Authors, 2017). This is particularly true among the 
research-intensive universities which serve as the first-tier in a stratified HE system while colleges comprise the second-tier and are oriented mainly towards teaching. The different aims of these two types of institutions is expressed also in their rationales for internationalisation. Depending on the size, location, disciplines and student composition, colleges tend to focus on internationalisation to retain academic staff and compete with universities, prepare students for the 'global knowledge economy,' and to foster inter-group relations within their diverse student populations (Authors et al, 2015). A view of internationalisation as the pursuit of academic excellence is especially prominent at the elite research-oriented universities, which is enacted primarily through international research and partnerships with other elite institutions. Thus, the universities are characterised by a much greater emphasis on research with impressive performance on global quality metrics including international research funding, publication, and citation rankings (Marginson, 2006) with less emphasis on student mobility than is common in other OECD and EU countries. However, incoming student mobility has not been ignored. Rather, it has been fostered primarily as a connection to the Jewish diaspora, at the level of study abroad and nonresearch degrees (see Authors, 2018; Donitsa-Schmidt \& Vadish, 2005) and as a tool for increasing research quality and solidifying connections with nations to whom Israel would like to draw closer ties at the level of research. In line with these ambitions, in 2017, the Council of Higher Education ( $\mathrm{CHE}$ ) introduced internationalisation as a pillar in its new multi-year plan which aims to internationalise Israeli HE by promoting English language instruction, building and improving international infrastructure and national bureaucracy, and recruiting international research students to Israel. The primary aim of this initiative is to raise the academic quality of HEls with international research students viewed as a key component. Research students from China and India; and the Jewish diaspora, particularly from North America and Western Europe are targeted through this initiative (Maoz, 2016). These different target groups reflect the contemporary purposes of Israeli internationalisation; Chinese and Indian students to cement ties with large emergent economies to propel research (and the Israeli economy) forward; and Jewish students from the diaspora in line with Israel as the homeland of the Jewish people and as a source of potential immigrants (Authors, 2018). Reflecting these themes, AU participants largely viewed internationalisation in relation to research and an international student programme with the Jewish diaspora. Given that these were the areas which were of greatest focus for the institution, other 
important issues of internationalisation, for example internationalisation of the curriculum (IoC) (see Trahar (2018) for a reflective study on loC in Israeli colleges) are not addressed in this study.

A final feature that affects internationalisation of Israeli higher education, and is the partial success of the Palestinian campaign for the academic and cultural boycott of Israel (PACBI) launched in 2004, which spurred the boycott, divestment, and sanctions (BDS) against Israel movement. This aims to return the lands occupied in 1967 and to dismantle the wall around the West Bank; to recognise equality for Palestinian citizens of Israel; and to promote the right for Palestinian refugees to return to what is now Israel, Gaza, and the Occupied Territories. While Munayyer (2016) focuses on the growth and successes of the movement over its first decade, particularly in stimulating civil debate in the US and elsewhere, according to Newman (2016), despite broad media coverage, these actions have achieved limited success and have only had serious impact on Israeli-Palestinian cooperation. Palestinian academics have come under pressure from their own authorities to cease any joint activities with Israelis, as such cooperation is presented increasingly as normalising the status quo.

\section{Ariel University: historical development of a political institution}

Since its inception, AU has been locked in a constant struggle for recognition and legitimacy not only from a legal and academic standpoint, but also from the Israeli public. AU was established in 1982 as the Academic College Judea and Samaria, an extension of Bar Ilan University. It was initially located in the small settlement of Kedumim in the West Bank and was created to bring enrichment and vocational training to Jewish settlers there. In 1987, the college moved to the larger West Bank settlement of Ariel and since the early 1990s, with the support of right-wing governments and under the leadership of Member of Knesset (Parliament) Yigal Cohen-Orgad, the college set a goal to become a university. Initially, the college enrolled students mostly from other Jewish settlements in the West Bank, however over time, AU began to absorb students from Israel including a significant number of new immigrants from the former Soviet Union (FSU), from Ethiopia and other students from the periphery and disadvantaged backgrounds, including Palestinian Arabs with Israeli citizenship. Seeking to conduct research the college developed faculties and research labs for engineering and the natural sciences, hosted scientific conferences, and encouraged its faculty to publish 
in internationally recognised journals (Davidovitch \& Iram, 2014). In this way, AU departed from the teaching intensive activities pursued by most colleges.

In 1992, the college applied for accreditation to confer undergraduate degrees. The request was denied by the Council of Higher Education ( $\mathrm{CHE})$, the Israeli entity charged with accreditation and quality assurance of HEls, on the grounds that Israeli law does not extend into the oPt. To circumvent this issue, the Israeli government established a dedicated agency for the sole purpose of accrediting and supervising the college; the Council of Higher Education Judea and Samaria (CHEJS), which was empowered by an Israel Defence Forces (IDF) General, who serves as the acting Governor of Judea and Samaria. In 2004, the college ceased its affiliation with Bar Ilan University and was granted independent college status under the CHEJS.

In 2005, the government announced its intention to upgrade the college into a university in order to strengthen the education system in the region and enable further development of Judea and Samaria (part of the oPt) (Davidovitch \& Iram, 2014). The college was thus a means to entrench and extend Israeli control over the region. The decision was heavily criticised by the $\mathrm{CHE}$ and other universities in Israel that petitioned the Israeli High Court (which eventually upheld the decision) claiming that academic, budgetary, and planning considerations were overlooked in the decision-making process (Bob \& Lazaroff, 2013). In addition to these challenges to its legitimacy, many prominent Israeli academics criticised the decision on political grounds arguing that 'it was wrong to establish a university in an occupied territory, where the regime is oppressive to the people and therefore to the spirit of academia' (interview, former Senior CHE official). Prof. Manual Trajtenberg, former head of the Planning and Budgeting Committee (PBC), the funding arm of the $\mathrm{CHE}$, remarked in an interview with Haaretz, 'this university serves one purpose and one purpose only and that is to undermine any future possibility for a peace agreement with the Palestinians by making evacuation of the [West Bank] settlements that much harder' (Maltz, 2017). Thus, the legitimacy of the institution has been continually contested. The government decision was subject to review by a CHE committee of the means and funds required to realise this transformation. Despite the political debates around the decision, the formal discourse of the committee was limited to the academic and financial criteria for the college to become a university. The committee 
reviewed the matter and recommended a timeline of actions for the academic improvements required to obtain university status. Following the successful completion of this process, the CHEJS granted the now Ariel University, temporary university status which became official by an executive order of the military governor. In 2013 , the recognition became final and AU became Israel's ninth research university, albeit still supervised and regulated by the CHEJS. Over the years, several colleges have developed research programmes and attempted to challenge government funding schemes that favour universities. Thus far, $A U$ is the only college which has attained university status.

In February 2018, amid a storm of controversy, the Israeli Knesset voted (56 to 35) in favour of an amendment to the CHE law, dubbed the 'Ariel University Law,' that made AU subject to the jurisdiction of the $\mathrm{CHE}$, abolishing the former $\mathrm{CHEJS}$ and extending regulatory control over the institution. This move applied Israeli civil law to the West Bank and was viewed by some as akin to annexation (Lis \& Tzur, 2018; Lazaroff, 2018). AU, now with 15,000 students and an academic staff of over 300 researchers (compared to 80 in 2003 and 217 in 2012 (Davidovitch, 2014; Sinuany-Stern, \& Druckman, 2016)) has four faculties and operates 26 academic degree programs. Although it enjoys the same legal status in Israel as the other eight research universities, due to its location, $A U$ is banned from participation in many international research agreements and funds which do not support Israeli research in the oPt. Notably, the European Union (EU) programmes, such as Horizon 2020 and Erasmust; the German-Israeli Foundation for Scientific Research and Development (GIF); and the Israel-US Binational Science Foundation (BSF) and Binational Industrial Research and Development Foundation (BIRD) among others (Gordon \& Pardo, 2014). Thus, AU faces several distinct constraints which affect the nature and purposes of internationalisation. From the interviews of AU staff it emerged that the perceived constraints comprise four components: political and security issues associated with the location of $\mathrm{AU}$; international bans; perceived sabotage of $\mathrm{AU}$ initiatives by other Israeli institutions; and lack of status and quality researchers.

Firstly, due to the location of the university in an area considered occupied and sometimes perceived as dangerous, some scientists will collaborate with academic staff in Ariel, but will not visit the university, for moral reasons. Others are fearful to visit an area prone to terrorist activity. 
Secondly, as noted above, many international funding and mobility programmes exclude the participation of HEls located in the oPt. Thus, in contrast to other Israeli universities, AU is ineligible for important international cooperation (e.g. Horizon 2020; student and staff mobility schemes (Erasmus+); GIF, BSF). International bans are widely perceived not only as a constraint to internationalisation but as a challenge to the legitimacy of the institution.

Thirdly, and prominently throughout all interviews, the academic staff and administration were united in thinking, with some justification, that the other Israeli academic institutions try to prevent $\mathrm{AU}$ from receiving funds and building their international academic reputation. One anecdote mentioned by several interviewees, went back to when AU was still a small college. They received research funding from China for a project proposed by an AU researcher, to an Israeli academic committee screening projects for the Chinese government. The Chinese insisted the research from AU be done, even though the Israeli committee did not approve it. After intervention from the AU administration, the collaboration eventually proceeded. All interviewees spoke of sabotage and emphasised that, while Israeli researchers collaborated with them personally, the administration of the universities and academic establishment in Israel, were trying to marginalise AU.

Fourthly, is the lack of status and quality researchers. Being Israel's youngest university, AU has far less reputation, a smaller, less experienced academic staff with fewer publications and is less able to attract prominent researchers.

These constraints are related and work together to compound difficulties in international cooperation. For example, studies show the importance of researcher mobility and international collaboration on the quality, quantity and impact of publications (Dubois, Rochet, and Schlenker, 2014; Halevi, Moed, and Bar-llan, 2016); thus, the lack of status, may be exacerbated by the exclusion from international mobility and cooperation schemes.

Considering all of these constraints and the political turmoil surrounding the institution, why would researchers choose to work at AU? Several reasons were given in the interviews, ranging from the intense competition for academic posts, to the challenge and excitement of 
building a new department or research area in a young university. Yet it is important to note as well that it was not always clear to academics before they began at $A U$, the extent to which their activities would be restricted. For example, this senior academic reflects on his initial experiences with these restrictions:

This German friend tells me we're going to apply for a GIF together, and we're going to get it. I was happy, and then I come here [AU], and they tell me I can't apply for a GIF... it was a big mental blow...and then I discovered you can't do this and can't apply for that...I walked into a new reality. I understood I need to survive at the university. (Senior Academic \& Administrator 1)

It is difficult to understand how academics could be unaware of the restrictions on their research before taking a position at $A U$ however, this may be due to its dual status. Domestically, AU is considered a fullly-fledged university and thus eligible for all domestic research funding and collaboration on an equal footing with other Israeli universities, however, internationally, it is ineligible for many research funds and mobility schemes.

\section{Rationales for internationalisation at $\mathrm{AU}$}

Two guiding rationales for internationalisation emerged from the analysis. First, for the university administration, it is to achieve legitimacy for its existence and operation in an area considered as occupied by most of the international community. The administration uses international achievements by academic staff to normalise the institution and to quell critiques of its legitimacy from domestic and international sources. Second, for the academic staff, internationalisation is separated from politics and associated with the pursuit of scholarship, research collaboration, funding, and recruitment of international research students. Below we elaborate on these two rationales in detail.

\section{Administration}

The university administration considers the university to play a key role in achieving two national goals. Firstly, educational projects that support strategic goals of the state including the development of knowledge in fields important to the national interests, such as engineering, science, and recently medicine and education; access to HE for underdeveloped 
populations; and the integration (and attraction) of new (Jewish) immigrants. While universities develop academic programmes for a variety of reasons, including academic and economic, at $\mathrm{AU}$ the role of national needs in the development of academic programmes is supreme. A senior academic emphasised the priorities of $A U$ thus:

The university has a national mission... why don't we open a Faculty of Law? It's not a national need...it's a waste of time. We do not see a national need to add another Faculty of Law in Israel, although financially it will bring quite a bit of money to the university. (Senior Academic 3)

In Israel, there is an overabundance of lawyers and so the opening of a Faculty of Law is dismissed, in line with the national mission of the university. National needs have also been particularly salient in the debates surrounding the new medical school. Thus, the development of particular academic fields stems neither from financial motives, nor from academic reasons but rather from national needs.

Exemplifying the role of national needs further, an administrator of Masa Israel, a projectwhich brings young diaspora Jews to Israel and will be discussed more in Strategy \#2, expressed the aim of the programme as follows:

There were 50 students in the first year of Masa. And how many have made Aliyah [immigration of Jews to Israel] until now? According to our work, about $50 \%$ immigrate immediately, and over time, within a year and a half, another $20 \%$. That's $70 \%$ of participants! (Administrator 1 )

Thus, this programme contributes to the immigration and integration of diaspora Jewish youth into the country, in line with the states priorities. Moreover, AU administrators emphasised that it is not a profitable programme, and instead highlighted the ideological and national reasons for pursuing the programme in the absence of a financial motive.

Secondly, is the University's role in support of the Israeli occupation and Jewish settlement in Judea and Samaria (part of the oPt). The university administration considers the physical 
growth of the university (e.g. buildings, laboratories, scientific institutes) and the growing student body, as major achievements for the development and normalisation of the Jewish settlement in the West Bank. In this way, AU serves as a means to incorporate the oPt into Israel proper.It also serves to encourage and legitimate the movement of Israelis into the oPt. A senior leader of $A U$ put it thus:

We have 15,000 students, $85 \%$ of them do not come from Samaria [but from Israel]. Do you understand the only reason people come from all over Israel, in and out of Samaria... is the university? (Senior Academic \& Administrator 1)

The Governor of the AU articulated the two-fold mission of the university in a television interview:

Promoting two causes simultaneously, the matter of higher education for a very broad segment of the population, with the other cause, of re-enforcing Jewish settlement in Judea and Samaria (Cohen-Orgad, 2013).

These aims combine to connect the development and growth of the university with the normalisation of the Israeli occupation of the West Bank. In this context, the administration viewed internationalisation as an effective tool for attaining legitimacy, particularly when faced by domestic criticism from the academic establishment. For example, when AU recently applied to open a medical school, criticism again surfaced on academic, budgetary and political grounds, and the administration used gains from internationalisation to answer it:

We have joint research projects with over 30 hospitals and medical research institutions around the world, and the reason I know this, and had it looked into recently, is that we used it for our application to the CHE to open our medical school. (Senior Administrator 1)

International references were also used to demonstrate the recognition and worth of $A U$ degrees, in the context of domestic attacks on its academic quality: 
Interviewer: Are degrees from Ariel recognised by other universities in Israel? Cohen-Orgad: Of course, we are recognised by the $\mathrm{CHE}$ and all the universities in Israel.

Interviewer: So, someone who has a BA and wants to be accepted at Tel Aviv University...?

Cohen-Orgad: ...Yes.... let me put it differently. We have scientific cooperation with hundreds of researchers in Israel and around the world. Interviewer: In Oxford they would accept me with a BA from Ariel? Cohen-Orgad: In Cambridge, during the peak of the period in which England tried to boycott Israel, not just Ariel but all Israeli universities, we had professors on sabbatical in Cambridge and they published in the Newton Institute articles -

Interviewer: With a BA from Ariel can I be admitted to Harvard?

Cohen-Orgad: BA from Ariel, in my estimation would admit you to Harvard.... (Cohen-Orgad, 2013)

In these examples, $\mathrm{AU}$ uses internationalisation to quell domestic attacks on its legitimacy and reinforce its status. International connections particularly with reputable institutions - or even hypothetical connections as in the quote above - thus serve to normalize and defend the pariah institution.

In parallel, any boycotts or exclusions from abroad are treated as a threat to the university's legitimacy and quickly addressed by the Administration. Two examples were widely recounted. One, the university was excluded from an architectural competition in Spain and as a consequence, the university successfully sued the Spanish government, receiving a settlement of $€ 100,000$ (Eichner, 2016). Two, a university academic staff member was prevented from giving a talk in a conference in Los Angeles, and the university solicited the aid of a scholarly organisation to condemn the event. These cases have become part of the university's strategy of challenging any threats to its international activities which might delegitimise its status. Combatting international threats to AU's legitimacy (and as an extension, to the policies of Israel concerning the settlements), are handled as long-term, strategic objectives with the eventual aim to remove all barriers and bans to its existence. 
A significant challenge that the university wishes to eliminate, are the various international funding bans directed at the institution. While AU serves many marginalised populations (e.g. Ethiopian students, new immigrants), in interviews, the $6 \%$ Palestinian Arabs with Israeli citizenship were often mentioned along with the presence of a few Palestinian Arab students. Moreover, AU leadership stressed its intention to use the newly proposed medical center to serve the Jewish and local Palestinian population, echoing similar statements by Prime Minister Benjamin Netanyhu and Minister of Education Naftali Bennett at the foundation stone laying ceremony of the medical school (IsraeliPM, 2017; Naftali Bennett, 2017). AU also conducts research on a few projects designed to promote the welfare of Palestinians. The way this was portrayed in interviews, suggested that the purpose of these initiatives is to strengthen the legitimacy (and expansionist aims) of the institution and specifically to address international funding bans:

Together with Palestinian researchers, we developed a method that burns wood for charcoal doing less damage to the Palestinians working with it. You get something that produces no soot. But for this project, we cannot apply to the EU or to grants funded by the US foreign ministry...a better deal with the EU could be achieved, saying that if we do research that promotes the economic or environmental needs and interests of the Palestinian population, these will be exempt [i.e. be able to receive EU funds]. (Senior Administrator 1)

Thus, while international achievements are highlighted to quell domestic attacks on its legitimacy and advance expansionist aims, domestic initiatives with marginalised populations, particularly with Palestinian Arabs (those with and without Israeli citizenship), were highlighted in interviews to legistimise domestic expansion and combat international funding bans.

\section{Academic staff}

The rationale for internationalisation for AU's academic staff is the improvement of scientific research which was perceived as intrinsic to the nature of academia and vital for progress. 
While teaching activities were considered important, particularly to achieve national and social aims, the academic staff saw their primary responsibility as scientific research. They widely described a circular process in which quality research begets funding which begets research students which then perpetuates the whole process in an upwards spiral towards better quality research, more funding and superior research students. Internationalisation was viewed as an important tool in advancing all three areas of this process: enhancing the quality of research; increasing access to research funding; and recruiting research staff, particularly doctoral and post-doctoral students.

In line with Proctor (2016), a secondary but linked rationale for internationalisation was related to the status and career progression of the researcher. The academic staff acknowledged the inferiority of their institution in relation to the established research universities in Israel; given this status, internationalisation was seen as a way for researchers to enhance their academic reputation, their research activities, and ensure promotion and progress in their careers.

I tell them [young academic staff] to go to conferences to make connections with other people, not to defeat the Boycott, but simply to develop your abilities as researchers, to develop in your field. In the end, for promotion in the higher echelons, you need recommendations from abroad. Today to get a promotion for full professor, you need six recommendations from Israel and six from abroad - exactly what the Technion is asking for. (Senior Academic 3)

While advancing research was the dominant rationale for the academic staff, one academic interviewed also considered lecturing on Jewish identity, bringing Jewish students from the diaspora to Israel, and introducing the work of the university to Jewish communities around the world as a significant rationale for internationalisation. This reflected her area of expertise, which includes Jewish education.

Finally, when asked about the political aspects of the institution in relation to their roles and specifically internationalisation, the academic staff sought to distance themselves from such 
motives. They considered themselves as scholars and 'people of science', and any mixing of politics in their work was viewed as inappropriate and even insulting.

I think I represent researchers here...we want to be scientists. And what is important for a scientist? To publish, to promote research, to guide students, and we don't care [for politics]. People came here because they want to be in the academy. They do not care for political things. All the time there are attempts to connect politics and academia and I think this is a mistake and it offends many researchers here. The only simple thing they want is to be researchers. (Senior Academic \& Administrator 1)

Any critical reflection about their research in relation to the institutional rationales or issues of social justice were conspicuously absent. Thus, while AU administration views internationalisation as a way to bolster legitimacy for the institution to achieve national goals, academic staff tend to consider the legitimacy rationale and the nationalistic aspects of the university's operation as immaterial. Instead they view internationalisation as an important tool to progress in their careers and to raise the quality of their research through international collaboration, funding and research students. Researchers made strong distinctions between their research and the political situation and professed to see little connection between the two. However, as mentioned earlier, researchers keenly understand - if not at the time they join $\mathrm{AU}$ - then quickly thereafter, how the political status of the institution affects the internationalisation of their research to its detriment (e.g. Boycott, international funding bans). Thus, there is an awareness of how the political status of the institution affects the internationalisation of their research, however, there is little consideration of how their international research is used to bolster the political claims of the university or the moral and social justice implications of conducting research at $\mathrm{AU}$.

\section{Enactment of internationalisation at $\mathrm{AU}$}

Despite differing rationales, administration and academic staff work in close collaboration to enact internationalisation through four distinct strategies: researcher-led collaboration; leveraging/using shared personal characteristics and cultural attributes; bending the rules of 
the EU ban; and national funding as substitute for international funding. Below, we analyse each strategy in more detail.

\section{Strategy \#1: researcher-led collaboration}

While in most Israeli universities international partnership agreements tend to be pursued and handled by senior administrators, in $\mathrm{AU}$, researchers take the dominant role in establishing partnerships. From the Administration's perspective, the academic staff are responsible for the creation and establishment of not only their scholarship activities (e.g. laboratories, research institutions, teaching) but also for international collaborations. Building on established personal connections, researchers are best positioned to initiate collaboration on the individual level. The university leadership then attempts to build on these personal connections to forge institutional relations. The process was described thus:

Let's say [researcher] was on sabbatical in Australia, and he comes back and says, 'Melbourne University is ready to sign a collaboration agreement with us'. So, I get an agreement ready, that's how we operate. (Senior Administrator 1)

Moreover, once institutional partnerships are completed through the work of the individual researcher, the Administration then moves to promote the partnership to other researchers at $\mathrm{AU}$ :

A...We have a professor who was born in Denmark. He studied there and came here...he is a professor here, but he has an agreement with a Danish university.

Q: And this agreement will become something the university will gain from beyond him personally?

A: Of course...there is nothing personal, any agreement....is between the universities. (Senior Academic \& Administrator 2)

The Administration does not actively try to initiate partnerships, rather they support the efforts of academic staff and seek to strengthen and expand these relationships to the benefit of the institution as a whole. Thus, cooperation which begins between individual researchers, can then be extended to the entire university, showing how small individual connections can 
be transformed into official, institutional partnerships. This move from the personal to the institutional level, includes mutual visits by heads of universities and can be extended even to state level cooperation.

I offered the Ministry of Science contacts with Russia and Ukraine and these were agreements between the countries that I caused to happen. We have a shared research fund with Ukraine and with Russia as well... we've been collaborating for 16 years. All the time, here and there. And we've had funding and two monographs and dozens of articles and joint students. That's how it happened. (Senior Academic \& Administrator 2)

While the literature emphasises the important role of academics in the internationalisation of research, at $\mathrm{AU}$, the researcher takes the lead in establishing partnerships for the entire university while the Administration acts more as an administrative support. This strategy suggests that when an institution has weak legitimacy; either from its pariah status or from lack of prestige, institutional internationalisation may rely more heavily on its academic staff which may be leveraged by the administration to achieve their aims that otherwise would probably be unachievable.

\section{Strategy 2: using shared personal characteristics and cultural attributes}

This strategy addresses the targets of internationalisation at $\mathrm{AU}$. While researchers are open to collaboration with partners from around the world, they tend to pursue partnerships based on shared personal characteristics and cultural attributes, which makes collaboration easier, given the constraints. These include Russian-speaking researchers, countries and expatriates; and certain elements of the Jewish diaspora. The map below (Figure 1, after references) derived from the AU website, illustrates the HEls that cooperate with $\mathrm{AU}$. It shows a clear inclination to collaborate with institutions in Eastern Europe and the former USSR which stems mostly from the background of many AU researchers, who immigrated to Israel from former Soviet countries during the 1990s and the scarcity of other alternatives. Their knowledge of the language, culture and academic practices of the former Soviet nations has eased access and led to collaborative research projects and conferences, recruitment of 
doctoral and post-doctoral students, research funding and even donations. As the interviewees explained:

[We cannot] work with the EU, so you try to find markets where you can work. We speak Russian, and in these countries, this is a major advantage... and there are strong scientists there and I regret to say, that the academic situation in Russia is not so good. (Senior Academic staff 4)

People [doctoral and post-doctoral students] look for the most prestigious places, and because we have connections to Russia we thought that we can get the strongest potential from there. We also succeed in bringing students from the Ukraine, Russia, and Saint Petersburg for doctoral and post-doctoral studies, because over there they don't have many options, but they have great potential. You bring them here, you invest a lot in them, and they have very high work ethics, and are intellectually very strong. (Senior Academic \& Administrator 1)

While it is noticeable that $\mathrm{AU}$ focuses on internationalisation primarily through its research, one of the few, and certainly the largest international student programme that $\mathrm{AU}$ hosts is the Masa Israel project. Masa is an umbrella organisation founded by the Jewish Agency for Israel and the Israeli government which brings students from the Jewish diaspora to spend a period of between 5-11 months in Israel in a variety of programmes, including academic ones, based in universities. The programme offers funding to young Jews from the diaspora and is designed to foster a relationship between the diaspora and Israel. Unlike many of the established universities (and some colleges) in Israel, AU has not developed international study abroad or degree-granting programmes, taught in English. While in most Israeli universities the Masa-eligible programmes are taught in English, and targeted towards North Americans and Western Europeans, at AU, Masa takes on a Russian dimension.

I had a very successful programme there $[A U]$ in Russian. It was like a pre-aliyah mechina [foundation year for new Jewish immigrants] that was very popular. We tried to develop a French-speaking programme but that closed and I think 
they were fully aware of what would happen if they tried to open an English programme for American study abroad kids. I don't think they would have found a single [US] university that would collaborate with them because it's super problematic. And they understood that...but again, it's a recognised university and their Russian programme was actually really good. It was always full. ...they had great staff. Their students were super happy... but it fits the right crowd. It's the crowd that really didn't care about those kinds of [political] issues. (Former Masa Israel Director)

Russian students are the target group for this programme because the university can support them, given the background of its staff, and the political turmoil surrounding AU is viewed as less important to them. Trying to appeal to Jewish students from other parts of the diaspora failed, thus, it appears that a programme built around shared personal characteristics and cultural attributes, succeeded in working with the Russian students because they did not have strong political opposition to AU. This demonstrates that shared personal characteristics (e.g. religion; ethnic group) and cultural attributes (e.g. language) do not necessarily trump strongly held political views, rather, they may work together to promote or inhibit internationalisation.

This strategy illustrates not only the importance of personal characteristics and shared cultural attributes in building strategic relationships for internationalisation, but also the importance of political views, in this case towards AU and the Israeli settlements in the oPt. While Woldegiyorgis et al (2018) argue that individual academic features (e.g. graduate research training; discipline; mobility opportunities) affect the internationalisation of research, this strategy demonstrates that it is also the personal characteristics and cultural attributes of researchers. Evidence from the Masa programme at $A U$, emphasises that personal characteristics and shared cultural attributes are helpful to facilitate international student mobility but these do not trump strong political views. As there is evidence of relatively little AU cooperation with countries that express more critical views towards Israeli settlements in the oPt, this suggests that politics also plays a role in the internationalisation of research. 
Internationalisation strategy \#3: bending the rules

This involves undermining and distorting the rules of international bans, particularly in reference to the EU. AU collaborates with European partners, however unlike other Israeli HEIs, they cannot receive EU funds for their projects. However, some AU researchers do take part in EU-funded projects, led by academics from other universities, while some AU academic staff take part in Erasmus+ projects using alternative academic affiliations. These academics explained succinctly the methods used:

If I have a cooperation that requires European intervention, then I do it through another university where the chief investigator will be from there... I'm not looking for fights that I will not gain from. Wherever we want to submit [funding applications], if there is something suitable for a European or American fund, so he will submit it there and I will not be the lead investigator. I will swallow my dignity and I will not be the principal investigator. I am contributing no less than him, and we will continue this research in some framework. (Senior Academic 3)

They [Europeans] need the knowledge. So, Tel Aviv [University] approached me and I collaborate with them in an Erasmus project. How do I do that? Because, you know I am from Ariel. So, what do I do? My other hat is Head of [a Professional Organisation]. So, if it doesn't come from here it will come from there. But the person stays the same. That doesn't change. (Senior Academic 1)

Despite difficulties cooperating with Western Europe due to EU regulations which forbid funding of research projects in the oPt, cooperation with institutions and scholars in Western Europe is still common. These tend to be carried out through another university or the regulations are - intentionally or not - interpreted to access EU funding. This strategy lends empirical support to Gordon and Pardo's (2014) arguments that the EU restrictions on funding has 'a positive normative impact on the self-identification and self-conception of the Union population, but only a minimal impact on Israeli practices' (p. 2); and serves to legitimise and further entrench EU-Israel relations. Moreover, this raises an unexplored issue related to the EU ban; while researchers may find ways to participate in EU networks and receive funding from alternative sources, students are unlikely to find alternative paths to mobility (i.e. 
Erasmus+). Thus, the bans have more of a negative impact on AU students than researchers. Additionally, it was difficult to assess in our study if international research conducted in this circuitous way, was counted as part of the international portfolio and partnerships at $\mathrm{AU}$ and thus included in claims for legitimacy by the Administration.

Internationalisation strategy \#4: national funding as substitute for international funding International funding, particularly from the EU, is an important source of funding for Israeli universities, which is denied to AU. The Israeli government signed Horizon 2020, which excludes $A U$, only a few months before Ariel was granted university status. The lack of EU funds, appears to be compensated for by research and other services procured without public tenders from branches of the Israeli government. This source of revenue is significantly larger than any other university. Between 2007 and 2016, AU received 162 million NIS for such services, while the next highest recipient, Tel Aviv University received 96.7 million NIS (Karofsky, 2016). AU carries out applied research, tailored to the needs of Israeli defense systems and other branches of the Israeli government and private companies including the Administration for the Development of Weapons and Technological Infrastructure (MAFAT), Israeli Aerial Industries, Elbit (private defense company), Bezeq (telecommunications), Israeli Electric company and the Israeli Railways. Except for researchers from the departments of archeology and education, academic staff noted that their research was significantly influenced by this cooperation with government. Inevitably this source of funding requires many researchers to focus on the national/security implementations of their research. $A$ senior researcher from engineering explained the choices he faced:

In my opinion, if I were today at the Technion, I might turn to the European Union and tell them let's do something for peaceful purposes...But meanwhile I do not get funding from anyone, so I must do my own financing. If I look for funding today, I will probably try to interest a military body... but the research begins out of a curiosity of whether I can implement algorithms of bats or fireflies on a series of drones. I have a drone here, if you have 100 of them and you want to carry out a mission with them, then the task can be a military one to defend a certain border or attack a site. Or alternatively my task could be to 
go and dust persimmon trees...the problem is to do it here (AU), I don't know if the Ministry of Agriculture will fund me and Europe might have funded me generously because it is a popular area now... but they will not. So, I will try to go to MAFAT... (Senior Academic 3)

This strategy illustrates that with strong state support, national funding may compensate for the loss of international funding, however, it will also move the research agenda towards national, and in this case, military priorities.

\section{Discussion and conclusion}

We began by establishing the widespread framing of internationalisation: a value-neutral process driven predominately by economic motives yet widely viewed as a positive intervention. We asserted that this framing de-politicises internationalisation, focusing mainly on competition in a global race. Furthermore, the dominant strategy for achieving internationalisation involves different types of mobility, in which nations, institutions, and individuals exercise a large degree of autonomy. Through an in-depth study of internationalisation at $\mathrm{AU}$, an institution entrenched in political controversy, with a pariah status by virtue of its location and operating under severe restrictions, we developed and analysed the rationales for and enactment of internationalisation. Our analysis provides important insights about and challenges to the understanding of internationalisation both in the Israeli-Palestinian context, and more broadly.

While internationalisation is often depicted as a process driven by economic considerations we demonstrated that the economic motives for internationalisation are sometimes secondary. In the case of $A U$, it is based on a desire for legitimation (and thus, continued expansion) by the Administration, and academic motives by the researchers. The former is a political aim and unlike much of the literature which assumes a large degree of academic freedom and autonomy of institutions - and that the political rationales operate at the level of the state - in this case, internationalisation is harnessed to service national goals, and thus a political rationale is strongly evident at the institutional level. Pointedly, this study demonstrates the incongruence and cognitive dissonance arising from the academic rationales of researchers and the more political motives of institutional administrators. It 
draws attention to the ways researchers can focus on furthering their scholarship and can ignore the ostensible ways in which this is used for other, in this case, political purposes by the state and administrators. While it is well established that there are overlapping rationales for internationalisation, which at times could be in tension, in this case we show that the differing rationales of administrators and academics do not necessarily collide and are not perceived as in tension by the academics. In contrast to Trahar et al (2016), who highlight the disengagement of academic staff from internationalisation if institutional rationales for and practices of internationalisation are at odds, the difference of rationales at $A U$ did not result in the disengagement of academics from internationalisation. Indeed, researchers are its main facilitators. Researchers compartmentalise 'academics' and 'politics' with little recognition of the moral and social justice implications of their research. While this is particularly conspicuous in the $\mathrm{AU}$ case, the theme of compartmentalisation could be extended to the 'academic' and 'economic' rationales in neoliberal universities, in which academic staff may advance international research agendas (which add to the prestige of the university, boost rankings and facilitate international student recruitment) while ignoring the social justice implications for the treatment of international students in their own institutions (see, Tannock, 2018). Thus, this study raises important ethical concerns about researcher responsibility for social justice in the institutions in which they work.

Internationalisation still occurs under conditions of extreme political controversy, and under international bans. However, the strategies used to promote it have exploited the available opportunities for collaboration and has resulted in internationalisation reflecting personal characteristics and political positions, as opposed to its framing as a 'neutral' process. In the case of $\mathrm{AU}$, internationalisation is shaped by the shared cultural attributes of researchers; personal characteristics and connections; political positions; and attempts to 'hide' or manipulate rules regarding institutional affiliations. Thus, this study supports assertions that internationalisation of research is dependent on the individual academic features (e.g. discipline, graduate research training) but extends this to encompass personal characteristics and cultural attributes. Furthermore, this study shows how internationalisation is shaped by shared political views. While this is recognised as a basis for international cooperation in the Cold War period, this has been less developed in the post-Cold War period. 
This study unpacks the consequences and effectiveness of international bans on university internationalisation. In the case of $A U$, this has resulted in hardships to the university and it has restricted its (official) cooperation with researchers and mobility schemes in many countries. It has not halted the university's development - or internationalisation. It has however had several, likely unintended effects. For example, as noted in Strategy 4, the lack of international funding has been replaced by increased national funding, which effectively moves the research agenda towards national aims and particularly military applications, and away from peaceful applications. With reference to Strategy 2, this has the effect of reinforcing partnerships with researchers and students who may share similar personal characteristics and political positions, especially with regard to the West Bank, instead of fostering dialogue with diverse researchers from around the world with a range of views. Concerning Strategy 3, researchers appear to continue collaboration, circumventing the bans, however, students do not appear to have other outlets for mobility and are therefore more affected by the bans. Thus, the bans have the result of binding the university and its internationalisation ever tighter to nationalist aims, reflecting personal characteristics and political positions. Given this, it is important to rethink the goals of international bans and if they are producing the desired effects.

Finally, the literature largely depicts internationalisation as a competition at the global level, beyond national borders; we demonstrate the complicated interplay between the global and the local. Internationalisation may be used as a tool for domestic purposes; specifically, in the case of $\mathrm{AU}$, the University itself and internationalisation specifically is used to legitimise, expand and normalise the occupation - and by extension, government policy. Conversely, domestic activities with marginalised populations may be used to further international aims; in the case of $A U$, research and programmes undertaken in cooperation with and for the Palestinian Arabs with Israeli citizenship and the Palestinian community are evidenced as a claim for international funding, with the goal of legitimising the University's political role.

While this study develops significant insights about internationalisation in the IsraeliPalestinian context, it also has wider implications. Perhaps most importantly this study reinforces the need to regard internationalisation critically. Despite attempts to isolate internationalisation from political and ideological views through the use of a discourse which 
is imbued with the 'neutral' and/or positive vocabulary of 'science,' 'excellence' 'competition', 'choice' or 'the market,' this case strikingly illustrates that internationalisation is a political and ideological act, whether it be in the name of neoliberalism, cosmopolitanism, nationalism or otherwise. Finally, whilst we have focussed on internationalisation in one Israeli institution in the oPt, we suggest that the influence of politics is not unique to this case; similar forces are evident elsewhere; albeit to a different degree and as a manifestation of different political tensions.

\section{References}

Aktas, F., Pitts, K., Richards, J. C., \& Silova, I. (2017). Institutionalizing global citizenship: A critical analysis of higher education programs and curricula. Journal of Studies in International Education, 21(1), 6580.

Authors, $2014 ; 2015 ; 2017 ; 2018$

Bauer, M. W., \& Gaskell, G. (Eds.). (2000). Qualitative researching with text, image and sound: A practical handbook for social research. Sage.

Beerkens, E. (2004). Global opportunities and institutional embeddedness: Higher education consortia in Europe and Southeast Asia. University of Twente [Host].

Ben-Tsur, D. (2009). The impact of conflict on international student mobility: a case study of international students studying in Israel. International Studies in Sociology of Education, 19(2), 135-149.

Berry, C., \& Taylor, J. (2014). Internationalisation in higher education in Latin America: policies and practice in Colombia and Mexico. Higher Education, 67(5), 585-601.

Bob, Y.J. \& Lazaroff, T. (December 24, 2013). High court permits Ariel to remain a university. Jerusalem Post. Retrieved June 17, 2018 from: https://www.jpost.com/Diplomacy-and-Politics/High-Courtpermits-Ariel-to-remain-a-university-336013.

Brandenburg, U., \& de Wit, H. (2011). The end of internationalization. International Higher Education, 62, $15-17$. 
Chankseliani, M. (2018). Four Rationales of HE Internationalization: Perspectives of UK Universities on Attracting Students From Former Soviet Countries. Journal of Studies in International Education, 22(1), 53-70.

Cohen-Orgad, Y. (2013, November 17). Interview by T. Segev. Hiyu Yamin. [Television broadcast]. Jerusalem: Erutz HaKnesset. https://www.youtube.com/watch?v=24oWf7Nz4 w

Dattal, L. \& Linder-Ganz, R. (June 18, 2017). A massive donation and a Sheldon Adelson medical school: Israeli West Bank university to double in size. Haaretz. Retrieved June 17, 2018, from https://www.haaretz.com/israel-news/.premium-with-massive-donation-from-adelson-israeli-westbank-university-to-double-in-size-1.5485357

Davidovitch, N., \& Iram, Y. (2014). Regulation, globalization, and privatization of higher education: The struggle to establish a university in Israel. Journal of International Education Research, 10(3), 201218.

Davidovitch, N., \& Soen, D. (2009). A college as a lever for graduates settling in the region: A case study of the college of Judea and Samaria. Israel Affairs, 15(1), 66-80.

Davidovitch, N., \& Soen, D. (2010). The link between unit size and performance quality assessments of teaching and administrative faculty: A case study of the AU center of Samaria. College Student Journal, 44(1), 44-54.

de Wit, H. (2002). Internationalization of higher education in the United States of America and Europe: A historical, comparative, and conceptual analysis. Greenwood Publishing Group.

de Wit, H., Hunter, F., Howard, L., Egron-Polak, E. (2015). Internationalisation of higher education. Brussels, Belgium: European Parliament. Retrieved from http://www.europarl.europa.eu/RegData/etudes/STUD/2015/540370/IPOL_STU\%282015\%2954037 O_EN.pdf Donitsa-Schmidt, S., \& Vadish, M. (2005). North American Students in Israel: An Evaluation of a Study Abroad Experience. Frontiers: The Interdisciplinary Journal of Study Abroad, 11, 33-56. 
Eichner, I. (2016.01.06). Blow to BDS: Spain will compensate the University of Ariel for the expulsion of students. Ynet. Retrieved July 5, 2018 from https://www.ynet.co.il/articles/0,7340,L4749115,00.html.

Gao, Y. (2017). A set of indicators for measuring and comparing university internationalisation performance across national boundaries. Higher Education, 1-20.

Gao, Y. (2015). Constructing internationalisation in flagship universities from the policy-maker's perspective. Higher Education, 70(3), 359-373.

Gordon, N., \& Pardo, S. (2015). Normative power Europe and the power of the local. JCMS: Journal of Common Market Studies, 53(2), 416-427.

Guo, Y., \& Guo, S. (2017). Internationalization of Canadian higher education: discrepancies between policies and international student experiences. Studies in Higher Education, 42(5), 851-868.

Hammond, C. D. (2016). Internationalization, nationalism, and global competitiveness: a comparison of approaches to higher education in China and Japan. Asia Pacific Education Review, 17(4), 555-566.

Hammond, C. D., \& Keating, A. (2017). Global citizens or global workers? Comparing university programmes for global citizenship education in Japan and the UK. Compare: A Journal of Comparative and International Education, 1-20.

Hsieh, H. F., \& Shannon, S. E. (2005). Three approaches to qualitative content analysis. Qualitative health research, 15(9), 1277-1288.

Huang, F. (2006). Internationalization of curricula in higher education institutions in comparative perspectives: Case studies of China, Japan and the Netherlands. Higher Education, 51(4), 521-539. [IsraeliPM]. (2017, June 28). PM Netanyahu at Cornerstone Laying for Adelson Medical School at Ariel University [video file]. Retrieved from https://www.youtube.com/watch?v=cBao8velWtE Karofsky, S. (31.10.2016). How the State Turned Ariel Into the Most Budgeted University in Israel. Calcalist. Retrieved June 16, 2018 from https://www.calcalist.co.il/local/articles/0,7340,L$3700549,00 . h t m l$. 
Knight, J. (2015a). Internationalization: A decade of changes and challenges. International Higher Education, (50).

Kratz, F., \& Netz, N. (2018). Which mechanisms explain monetary returns to international student mobility?. Studies in Higher Education, 43(2), 375-400.

Larsen, M. A. (2016). Internationalization of higher education: An analysis through spatial, network, and mobilities theories. New York, NY: Palgrave Macmillan.

Lazaroff, T. (February 12, 2018). Knesset applies Israeli law to Ariel University in West Bank. Haaretz. Retrieve June 17, 2018 from: https://www.jpost.com/Israel-News/Israel-applies-sovereignty-overAriel-University-in-the-West-Bank-542446.

Leask, B. (2001). Bridging the gap: Internationalizing university curricula. Journal of studies in international education, 5(2), 100-115.

Lis, Y. \& Tzur, Y. (12 February 2018). Knesset Approves: Israeli Law will Pertain to Higher Education Institutions in the Settlements. Haaretz. Retrieved June 21, 2018 from: https://www.haaretz.co.il/news/education/1.5810964 (Hebrew)

Lomer, S. (2017). Recruiting International Students in Higher Education: Representations and Rationales in British Policy. New York, NY: Springer.

Maltz, J. (July 20, 2017). Why Adelson Is Pouring Millions Into an Israeli University in the West Bank. Haaretz. Retrieved June 17, 2018 from: https://www.haaretz.com/israel-news/.premium-whyadelson-pours-millions-into-a-west-bank-university-1.5431239

Maoz, L. (2016). Internationalism in Higher Education: International Students in Israel. Suggestions for Policy. Prepared for the Israel Council for Higher Education. Jerusalem, Israel.

Marginson, S. (2006). Dynamics of national and global competition in higher education. Higher Education, 52(1), 1-39.

Mok, K. H. (2007). Questing for internationalization of universities in Asia: Critical reflections. Journal of Studies in International Education, 11(3-4), 433-454. 
Morley, L., Alexiadou, N., Garaz, S., González-Monteagudo, J., \& Taba, M. (2017). Internationalisation and migrant academics: the hidden narratives of mobility. Higher Education, 1-18.

Munayyer, Y. (2016). BDS: Where it came from and where it is headed. Geographical Review, 106(2), 283287.

[Naftali Bennett]. (2017, June 28). Minister Bennett at Cornerstone Laying for Medical School at Ariel University [video file]. Retrieved from https://www.youtube.com/watch?v=cHj05DGTsIA\&t=20s Newman, D. (2016). The failure of academic boycotts. Geographical Review, 106(2), 264-269.

Proctor, D. (2015). Key trends in international education research 2011-14: What does the data tell us? International Education Association of Australia. Retrieved from https://www.ieaa. org.au/ierncontentarchive/key-trends-2

Proctor, D. (2016, December). Academic staff and international engagement: Motivations and drivers in Australian higher education (Doctoral thesis). University of Melbourne.

Qiang, Z. (2003). Internationalization of higher education: Towards a conceptual framework. Policy futures in education, 1(2), 248-270.

Schartner, A., \& Cho, Y. (2017). 'Empty signifiers' and 'dreamy ideals': perceptions of the 'international university' among higher education students and staff at a British university. Higher Education, 74(3), 455-472.

Seeber, M., Cattaneo, M., Huisman, J., \& Paleari, S. (2016). Why do higher education institutions internationalize? An investigation of the multilevel determinants of internationalization rationales. Higher Education, 72(5), 685-702.

Sinuany-Stern, Z., Davidovitch, N., \& Druckman, E. (2016). Assessing research and teaching performance in Israel's higher education system: The case study of AU. Creative Education, 7(11), 1604-1614.

Stafford, S., \& Taylor, J. (2016). Transnational education as an internationalisation strategy: meeting the institutional management challenges. Journal of Higher Education policy and Management, 38(6), 625-636. 
Stein, S., Andreotti, V., Bruce, J., \& Suša, R. (2016). Towards different conversations about the internationalization of higher education. Comparative and International Education/Éducation Comparée et Internationale, 45(1), 2.

Stein, S., \&, V. (2017). Higher Education and the Modern/Colonial Global Imaginary. Cultural Studies $\leftrightarrow$ Critical Methodologies, 17(3), 173-181.

Stromquist, N. P. (2007). Internationalization as a response to globalization: Radical shifts in university environments. Higher Education, 53(1), 81-105.

Svetlik, I., \& Braček Lalić, A. (2016). The impact of the internationalisation of higher education on academic staff development-the case of Slovenian public universities. Studies in Higher Education, 41(2), 364-380.

Tannock, S. (2018). Educational Equality and International Students. New York, NY: Springer.

Trahar, S. (2017). Learning to See the Person, Not the Culture or the Faith: Critical Reflections on Internationalizing Higher Education in Israel. European Education, 49(4), 276-292.

Trahar, S., Green, W., \& de Wit, H. (2016). The internationalisation of higher education. In J. Case \& J. Huisman (Eds.), Researching Higher Education: international perspectives on theory, policy and practice (pp. 24-41). London: Routledge.

Trilokekar, R. D. (2010). International education as soft power? The contributions and challenges of Canadian foreign policy to the internationalization of higher education. Higher Education; 59(2), 131-147.

Wang, L. (2014). Internationalization with Chinese Characteristics, Chinese Education \& Society, 47:1, 726, DOI: $\underline{10.2753 / C E D 1061-1932470101}$

Warwick, P., \& Moogan, Y. J. (2013). A comparative study of perceptions of internationalisation strategies in UK universities. Compare: A Journal of Comparative and International Education, 43(1), 102-123. Woldegiyorgis, A. A., Proctor, D., \& de Wit, H. (2018). Internationalization of Research: Key Considerations and Concerns. Journal of Studies in International Education, 22(2), 161-176. 
Map 1: AU international partnerships

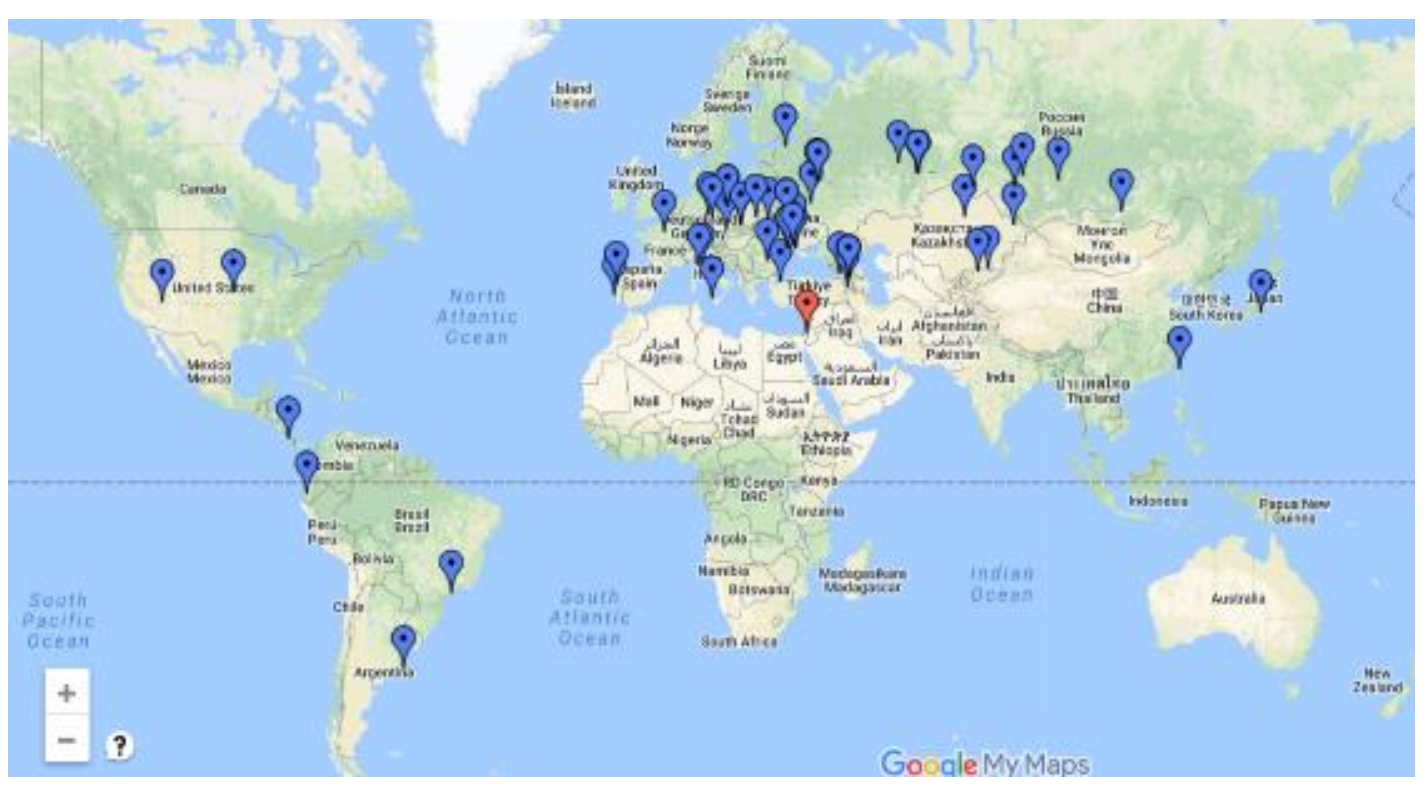

